\title{
DZIAŁALNOŚĆ I NAUCZANIE SŁUGI BOŻEGO STEFANA WYSZYŃSKIEGO - IMPLIKACJE PEDAGOGICZNE DLA POTRZEB PRAKTYKI PENITENCJARNEJ
}

Streszczenie: Wieloletnia działalność Sługi Bożego Stefana Wyszyńskiego na rzecz Kościoła w Polsce oraz obrony polskiej tożsamości uwidacznia się na polu odszukiwania oblicza współczesnych wartości, w kontekście wychowania, charakterystycznego dla chrześcijaństwa. Niniejszy artykuł w sposób syntetyczny ukazuje specyficzne rysy sylwetki duchowej oraz wybrane fakty z życia przyszłego błogosławionego, Prymasa Tysiąclecia Stefana Wyszyńskiego, jakie wyłaniają się na podstawie analizy jego działalności i nauczania. Źródłem wiedzy o Prymasie uczyniono jego przemówienia, kazania, homilie, notatki z czasu, kiedy był on więziony. Problematyka badań nad postacią i dziedzictwem Prymasa Stefana Wyszyńskiego uwidacznia się w potrzebie dociekań autora dotyczących doświadczeń wiary oraz możliwości wykorzystania poznawanej rzeczywistości w praktyce pedagogicznej wychowania resocjalizacyjnego.

Słowa kluczowe: Prymas Stefan Wyszyński; wychowanie chrześcijańskie; praktyka penitencjarna; godność.

\section{Wprowadzenie}

W swojej refleksji pragnę odwołać się do wybranych treści zawartych w wyjątkowym dziele, monumentalnej edycji źródłowej z lat 1948-1981, Stefan Wyszyński, „Pro memoria”, która składa się z 27 tomów. Dzieło to stanowi szczególny wyraz zainteresowania Instytutu Pamięci Narodowej losami Kościoła katolickiego w Polsce pod rządami komunistycznymi. Jego edycja była możliwa również dzięki wspólnemu zaangażowaniu Uniwersytetu Kardynała Stefana Wyszyńskiego oraz Instytutu Prymasa Wyszyńskiego.

* Dr Konrad Wierzbicki, Uniwersytet Kardynała Stefana Wyszyńskiego, Szkoła Wyższa Wymiaru Sprawiedliwości; email: k.wierzbicki@uksw.edu.pl. 
W tym miejscu pragnę serdecznie podziękować panu magistrowi Michałowi Stańczukowi z UKSW, który udostępnił mi poszczególne wydania wspomnianego dzieła, zachęcając do podzielenia się refleksją na łamach „Forum Pedagogicznego”, i tym samym do uczczenia Roku Prymasowskiego. Słowa podziękowania pragnę skierować również do księdza profesora Jana Niewęgłowskiego, redaktora naczelnego półrocznika, za życzliwość oraz za wszystkie cenne rady podczas opracowania mojej skromnej refleksji.

Jestem świadomy, że mając do czynienia z człowiekiem o tak bogatym życiorysie, jaki posiadał kardynał Stefan Wyszyński, trudno jest mi niezwykle zwięźle ocenić i przedstawić wszystkie fakty związane z jego życiem i działalnością.

Niemniej jednak spróbuję podjąć się próby analizy materiałów, którymi dysponuję, dzięki uprzejmości już wspomnianego M. Stańczuka, tak abyśmy mogli zrozumieć, z jak ważnym przykładem życia mamy do czynienia, tym samym zapiski kardynała Stefana Wyszyńskiego uczynić podstawą moich rozważań. Co więcej, treści w nich zawarte spróbuję odnieść w kierunku możliwości wykorzystania ich dla potrzeb praktyki penitencjarnej.

Osobiste zapiski prymasowskie (Zapiski więzienne) są odzwierciedleniem autentycznych jego odczuć i przemyśleń, jakie towarzyszyły mu na niełatwej drodze wypełniania swojego posłannictwa. Z pewnością po śmierci kardynała Wyszyńskiego zapiski były i w dalszym ciągu są przedmiotem zainteresowań wielu badaczy.

Już pierwsza analiza treści zawartych we wspomnianych materiałach ukazuje nam, że przykład duszpasterskiej troski kardynała Stefana Wyszyńskiego, bogatej w miłosierdzie wobec każdego człowieka, stanowić może pomocne „narzędzie” w działalności dydaktycznej oraz wychowawczej dzieci i młodzieży, a także resocjalizacyjnej skierowanej wobec osób pozbawionych wolności. Przejdźmy zatem do przedstawiania wybranych faktów z życia przyszłego błogosławionego, zaczynając od okresu, kiedy został on uwięziony.

\section{Wobec komunistycznego ucisku i oporu}

Kardynał Wyszyński był i jest wielkim autorytetem moralnym, posiadającym niezwykłą charyzmę, która w trudnym okresie zniewolenia komunistycznego w naszym kraju pozwoliła podejmować mu ważne przedsięwzięcia dla całej społeczności polskich katolików. Symbolem tych działań były m.in. obrady Soboru Watykańskiego II, w których aktywnym uczestnikiem był sam Prymas Wyszyński (Jan Paweł II 1971, s. 40-46). Już na początku swojej posługi prymasowskiej arcybiskup Stefan Wyszyński musiał stawić czoło nieprzychylnemu stosunkowi władz komunistycznych w Polsce.

Informacje na temat represji wobec Kościoła katolickiego możemy znaleźć m.in. na stronie internetowej Muzeum Historii Polski: „Pomimo podpisanego w 1950 r. porozumienia, dotyczącego nauczania religii w szkołach i funkcjonowania KUL, rok później usunięto siłą administratorów apostolskich z terenów Ziem 
Odzyskanych oraz aresztowano biskupa kieleckiego Czesława Kaczmarka. W 1952 r. wydalono z diecezji śląskiej i krakowskiej wszystkich biskupów. W lutym $1953 \mathrm{r}$. wydano dekret o obsadzaniu stanowisk kościelnych. Wydarzenia te wywołały reakcję ze strony najwyższych władz Kościelnych w Polsce. W maju episkopat ogłosił krakowski memoriał Non possumus, wyrażając sprzeciw wobec ucisku, jakiego doświadczało duchowieństwo katolickie. Na reakcję nie trzeba było długo czekać - 22 września zapadł wyrok skazujący na biskupa Kaczmarka, a 24 września rząd uchwalił także dla Prymasa zakaz «wykonywania funkcji wynikających z piastowanych dotąd stanowisk kościelnych [...] na skutek uporczywego nadużycia dla celów godzących w interesy Polskiej Rzeczypospolitej Ludowej». Nazajutrz aresztowano metropolitę w jego rezydencji przy ulicy Miodowej w Warszawie. Kazano mu zabrać tylko najpotrzebniejsze rzeczy, nie zważając na protesty hierarchy i domaganie się podstawy prawnej gwałtu na jego osobie. Przez następne trzy lata był internowany w Rywałdzie Szlacheckim (26 września - 12 października 1953), Stoczku Warmińskim (12 października 1953 - 6 października 1954), Prudniku (6 października 1954 - 29 października 1955) i Komańczy (29 października 1955 28 października 1956). Wraz z nim przetrzymywany był kapelan ks. Stanisław Skorodecki (który przybył do Stoczka po odbyciu wyroku w Rawiczu za opór wobec komunizmu) oraz siostra zakonna Maria Leonia Graczyk. Wolność zwrócono mu (oraz jego współwięźniom) dopiero 28 października 1956 r., kiedy wrócił do Warszawy, na Miodową" (www.muzhp.pl).

Tak Prymas Wyszyński opisywał okres swojego uwięzienia w Zapiskach więziennych: „Rozpoczynam więc życie więźnia. Słowa tego używać nie można, gdyż otoczenie moje prostuje: to nie jest więzienie. Pomimo to czuwa nade mną blisko 20 ludzi «w cywilu». Nie opuszczają korytarza i w dzień, i w nocy; skrzypiące kroki słyszę cały dzień. Brak nam światła. Jeden z młodych ludzi usadza się na noc na koślawym krzesełku pod drzwiami i tu, przy kopcącej lampce albo przy świecach ołtarzowych, czyta książki. Na podwórzu gospodarczym stale przebywa kilku młodych ludzi, którzy nie spuszczają oczu z moich okien. Zresztą, są grzeczni i trzymają się na odległość” (Wyszyński 1982, s. 26).

W Rywałdzie Prymas Wyszyński przebywał jednak zaledwie kilka dni. Już 12 października przewieziony został do Stoczka Warmińskiego. „Po kilku minutach jazdy zajeżdżamy przed jasno oświetloną bramę; świeci się wiele lamp. Brama jest obita świeżymi deskami. Jakiś niedostrzegalny duch otwiera bramę od środka. Wjeżdżamy w podwórze, które w ciemnościach. wrażenie więzienne. Pomyślałem, że przewieziono mnie do więzienia. Wóz zatrzymał się przed szeroko otwartymi drzwiami, wiodącymi na widny korytarz. Zaproponowano, bym wysiadł. Jesteśmy na korytarzu jasnym i pustym. Jednak «nie tędy droga». Znów jesteśmy w wozie po to, by wjechać przez wysoką bramę, zbudowaną ze świeżych desek, do ogrodu. Tu przez oszkloną werandę weszliśmy raz jeszcze na ten sam korytarz. Widocznie do «obrzędu instalacji» w nowym miejscu należały drzwi ogrodowe (Wyszyński 1982, s. 35-36). 
Tak prymas opisuje warunki, w których przyszło mu przebywać w Stoczku Warmińskim: „Ściany zewnętrzne do wysokości parteru zniszczone przez wilgoć, korytarze wewnętrzne mokre, zimne wnętrze, posadzki kamienne całe pokryte wodą. Oddano nam do dyspozycji korytarz i pokoje pierwszego piętra gmachu wychodzącego na ogród. Są tu dwa pokoje dla mnie, kaplica, pokój dla księdza, drugi dla siostry i kilka pokojów umeblowanych, pustych" (Wyszyński 1982, s. 38).

\section{Osobiste zawierzenie Prymasa Stefana Wyszyńskiego Matce Bożej}

Warunki towarzyszące pobytowi prymasa w Stoczku wpływały negatywnie na jego samopoczucie oraz stan zdrowia. „Niesamowicie marzły ręce i nogi. Nie pomogło nawet owijanie się pledem. Podobne kłopoty były w łazience, gdzie stary piec nie dawał się rozpalić; dymił na cały dom, pomimo wielokrotnego czyszczenia. Przez długi czas trzeba się było myć w zimnej łazience. Dokuczał nam również brak wody; stary motor ciągnący wodę często odmawiał posłuszeństwa. Byliśmy dość często bez wody, którą trzeba było przynosić $\mathrm{z}$ dołu. W końcu cały ten system zamarzł na kość. Podziwialiśmy sterty lodu, które wyrąbano z pokojów pod nami. Mieszkaliśmy nad lodowniami. Pokoje na dole nie były ogrzewane, natomiast były fantastycznie zagrzybione. Nikt nie dbał o to, by je ogrzać. Wszystkie korytarze pokryte były na ścianach białym szronem i zamrozem. Biedni dozorcy siedzieli w kożuchach i ciężkich butach. Męczyli się jeszcze bardziej niż my. Miny im posępniały. W takich warunkach zacząłem odczuwać różne dolegliwości. Nóg nie mogłem rozgrzać nawet w ciągu nocy. Ręce mi popuchły. Podobnie oczy mi zapuchły. Odczuwałem wielki ból w okolicy nerek i w całej jamie brzusznej. Każdego dnia przechodziłem bóle głowy. Siostra była stale zakatarzona, blada i wynędzniała" (Wyszyński 1982, s. 63).

Ósmego grudnia 1953 roku podczas pobytu w stoczkowskim więzieniu miało miejsce niezwykle ważne wydarzenie dotyczące osobistego zawierzenia i oddania się prymasa Wyszyńskiego Matce Najświętszej „(...) oddałem się dziś przez ręce mej Najlepszej Matki w całkowitą niewolę Chrystusowi Panu. W tym widzę łaskę dnia, że sam Bóg stworzył mi czas na dokonanie tego radosnego dzieła. Postanowiłem sobie, że pierwszą parafię, którą będę mógł erygować, uczczę tytułem „Bożego Macierzyństwa Maryi” (Wyszyński 1982, s. 48).

\section{Więzienie w Prudniku}

Kolejnym, trzecim już miejscem pobytu kardynała Stefana Wyszyńskiego, był Prudnik, w którym uwięzienie trwało od 6 października 1954 roku do 29 października 1955 roku. Jak opisano w kalendarium Zapisków więziennych 6 października 1954 roku o godz. 12.15 Prymas z towarzyszącymi mu osobami wyruszyli ze Stoczka do Kętrzyna, gdzie czekał na nich samolot. Wystartowano o godz. 13.00: „stały kierunek lotu - południowo-zachodni. Lecieliśmy w nieznane. Rozpoznaliśmy 
Jeziora mazurskie, przelot przez Wisłę. Później wznieśliśmy się ponad pułap chmur i już nic nie widzieliśmy, aż - Odrę. O godzinie 15.00 lądowaliśmy na polach, w pobliżu miasta, którego nie mogłem rozpoznać. Wiedziałem, że jesteśmy gdzieś na Opolszczyźnie. Później okazało się, że lądowaliśmy koło Nysy, skąd przez Głuchołazy dojechaliśmy samochodami do Prudnika Śląskiego" (Wyszyński 1982, s. 94).

Podczas pobytu w Prudniku nie było widać poprawy w stanie zdrowia Prymasa, dlatego w dniach 21-22 grudnia 1954 roku został poddany badaniom lekarskim. Tak opisuje prymas „świadczenia lekarskie”, na jakie mógł liczyć: „Przez dwa dni byłem w ręku «klinik» lekarskich w Opolu. Mówię «klinik», a nie lekarzy, bo lekarze działali, jak automaty: sprawnie, fachowo, niemal niezawodnie, ale bez duszy lekarskiej. Ci ludzie nie mają dla «nieszczęsnego pacjenta» - twarzy ludzkiej, której szuka się w lekarzu więcej niż recepty. Działa urzędnik, dla którego ważniejszą rzeczą jest propaganda niż medycyna. Jego sumienność, uprzejmość, wysiłek nie jest dla pacjenta, tylko dla «kogoś trzeciego», który każe zrobić dobre wrażenie, być grzecznym i sumiennym. Tak mocno czuje się tego «trzeciego», że schodzi się do rzędu «przedmiotu», biurokratycznego «kawałka» do załatwienia na specjalne zlecenie" (Wyszyński 1982, s. 120).

W trakcie pobytu w Prudniku w myślach i sercu Stefana Wyszyńskiego zrodziło się pragnienie ślubów jasnogórskich. Nawiązując do jubileuszu królewskich ślubów Jana Kazimierza, złożonych Matce Bożej w katedrze lwowskiej w 1655 roku, Prymas postanowił odnowić akt oddania Polski Pani Jasnogórskiej. W Zapiskach więziennych, będąc pod wpływem lektury Potopu, autorstwa H. Sienkiewicza, zapisał: „Warto myśleć o «obronie Jasnej Góry» roku 1955. - Jest to obrona duszy, rodziny, Narodu, Kościoła - przed zalewem nowych «czarów». Moja «Jasna Góra» ściśniona zewsząd wałem udręki; walą pociskami «zabobonu» $\mathrm{i}$ «wstecznictwa» w «Kurnik». Przed 300 laty «Kurnik» ocalał i trwa do dziś dnia. «Obrona Jasnej Góry» dziś - to obrona chrześcijańskiego ducha Narodu, to obrona kultury rodzimej, obrona jedności serc ludzkich - w Bożym Sercu, to obrona swobodnego oddechu człowieka, który chce wierzyć bardziej Bogu niż ludziom, a ludziom - po Bożemu" (Wyszyński 1982, s. 120).

W ponownym akcie oddania Polski Pani Jasnogórskiej kardynał Stefan Wyszyński widział program odnowy moralnej społecznej i Polaków.

\section{„Wszystko postawiłem na Maryję” - pobyt w Komańczy}

Pomimo stałego osaczenia przez władze komunistyczne, Prymas Wyszyński, jako duszpasterz wielkiego formatu, prawdziwie zaangażowany w sprawy społeczne - kontynuował pracę na rzecz narodu i Kościoła katolickiego w Polsce. Podczas pobytu w ostatnim miejscu odosobniana - Komańczy, powstało jego wielkie dzieło - Jasnogórskie Śluby Narodu, przelane na papier w dniu 16 maja 1956 roku. Wczytując się w treść Jasnogórskich Ślubów, zauważamy, że ich przesłanie 
dotyczyło troski o stan moralny Polaków jako całego narodu. W swoim dziele Prymas apelował o potrzebę podjęcia przez każdego człowieka pracy nad sobą, nad swoim charakterem, w kierunku pokonania słabości związanych z lenistwem, lekkomyślnością, marnotrawstwem, pijaństwem i rozwiązłością.

Analizując dostępne materiały źródłowe, dowiadujemy się, że w okresie uwięzienia kardynał Wyszyński opracował wiele ważnych inicjatyw duszpasterskich, związanych z kultem maryjnym. Wśród nich znajduje się dokonanie aktu prywatnego zawierzenia Matce Bożej, w trakcie pobytu w Stoczku, a w Komańczy - napisanie nowych strof przyrzeczeń w rocznicę ślubów lwowskich króla Jana Kazimierza. Jasnogórskie Śluby Narodu zostały odczytane następnie w święto Matki Boskiej Częstochowskiej 26 sierpnia 1956 roku.

Fala odwilży, jaka miała miejsce w Polsce w październiku w 1956 roku, pozwoliła na uwolnienie Prymasa z uwięzienia (www.muzhp.pl).

Kolejne lata prymasowskiej działalności dotyczyły wielkiego oddania w sprawy Kościoła i narodu, zaangażowania w sprawy opozycji i obronę osób represjonowanych. W 1957 roku Prymas powołał do życia Instytut Prymasowski Ślubów Narodu na Jasnej Górze - instytucję wspierającą prace Kościoła w realizacji programu Wielkiej Nowenny i przygotowań do Tysiąclecia Chrztu Polski (https://wyszynskiprymas.pl/instytut-prymasowski/).

Po wyborze Jana Pawła II na Stolicę Piotrową pojawiały się stanowiska mówiące, że wyniesienie Karola Wojtyły było także zasługą Prymasa Wyszyńskiego i jego autorytetu. Sam podkreślał to wielokrotnie Jan Paweł II: „Czcigodny i Umiłowany Księże Prymasie! Pozwól, że powiem po prostu, co myślę. Nie byłoby na Stolicy Piotrowej tego Papieża Polaka, który dziś pełen bojaźni Bożej, ale i pełen ufności rozpoczyna nowy pontyfikat, gdyby nie było Twojej wiary, niecofającej się przed więzieniem i cierpieniem, Twojej heroicznej nadziei, Twojego zawierzenia bez reszty Matce Kościoła, gdyby nie było Jasnej Góry i tego całego okresu dziejów Kościoła w Ojczyźnie naszej, które związane są z Twoim biskupim i prymasowskim posługiwaniem" (Audiencja dla Polaków, Watykan, 23 października 1978 roku).

Prymas Wyszyński postrzegał Karola Wojtyłę jako swojego następcę. Łączyła ich głęboka przyjaźń, miłość do Boga, Kościoła i Ojczyzny. Takimi słowami zwracał Ojciec Święty Jan Paweł II do Prymasa Polski: „Jezus Chrystus - «Książę Pasterzy» pozwolił Księdzu Prymasowi uczestniczyć we wszystkich swoich tajemnicach, zwłaszcza w tajemnicy bolesnej. Mówiąc za św. Pawłem - z łaski Bożej jest Ci dane dla Chrystusa nie tylko w Niego wierzyć, ale i dla Niego cierpieć. Z Apostołem Narodów może Ksiądz Prymas także powiedzieć, że jego posługiwanie przyniosło korzyść Ewangelii, bo więcej braci ośmielonych w Panu, wśród doświadczeń, coraz bardziej odważa się głosić bez lęku Słowo Boże. Oby to Słowo, które ma moc zbawienia, głoszone w naszym kraju z taką miłością i poświęceniem, zapuszczało korzenie w sercach wiernych i czyniło ich godnymi «synami królestwa Bożego»" 
(Depesza Ojca Świętego Jana Pawła II do Prymasa Polski, Watykan, 25 października 1979 roku).

Jan Paweł II wielokrotnie przywoływał postać Prymasa Wyszyńskiego w swoich przemówieniach, również po jego śmierci, która miała miejsce 28 maja 1981 roku w Warszawie, w uroczystość Wniebowstąpienia Pańskiego. Prymas Wyszyński miał wówczas 80 lat, z których 57 przeżył jako kapłan. Pogrzeb stał się wielką manifestacją narodową, trumna $\mathrm{z}$ jego ciałem spoczęła $\mathrm{w}$ podziemiach katedry św. Jana w Warszawie.

Tak Ojciec Święty Jan Paweł II wspominał Prymasa Wyszyńskiego: „Wgłębił się ten opatrznościowy Pasterz współczesnych pokoleń w naszej Ojczyźnie głęboko w myśl Kościoła, wsłuchał w bicie jego serca, w jego posłannictwo i sam stał się «posłannictwem». Przeprowadził Kościół w Polsce z pierwszego do drugiego tysiąclecia chrześcijaństwa. Tak jak przeprowadzał go szczęśliwie i wielokrotnie poprzez wiele momentów trudnych i poniekąd decydujących dla życia polskiego Kościoła i Narodu. A moc swą i światło czerpał z głębokiego, dziecięcego wprost nabożeństwa i z miłości ku Tej, która w Częstochowie «z dawna Polski jest Królową». Był on siłą Narodu, a jego siłą był Naród, na który patrzę z miłością i szacunkiem (Watykan, 5 lutego 1983 roku).

\section{W odkrywaniu dokonań i spuścizny kardynała Stefana Wyszyńskiego - uwarunkowania towarzyszące procesowi wychowania}

Wielość i różnorodność kwestii zawartych w nauczaniu Prymasa Wyszyńskiego dotyczących uwarunkowań towarzyszących procesowi wychowania stawia przede mną, poważne wyzwanie. Dlatego odniosę się do przedstawienia kilku wybranych zagadnień dotyczącej omawianej problematyki.

W literaturze przedmiotu mamy do czynienia ze zróżnicowanymi czynnikami wpływającymi na sukces działalności wychowawczej podejmowanej wobec dzieci i młodzieży, zwłaszcza tej wykazującej przejawy niedostosowania społecznego lub dokonujących gwałtownych czynów karalnych (Wach 2009). Również niekorzystnie na proces wychowania i rozwoju młodego człowieka wpływają dokonujące się współcześnie $\mathrm{w}$ świecie przemiany społeczne i kulturowe, związane z próbą przebudowy obrazu rodziny, która jak wiadomo - od tysięcy lat, składa się z rodziców oraz ich potomstwa.

Szczególnie widoczne w ostatnich miesiącach w Polsce ataki środowisk liberalno-lewicowych na symbole i wartości ogólnoludzkie, chrześcijańskie oraz święte dotykają funkcjonowania rodziny oraz jej członków. Przedstawiciele tych środowisk, demonstrując swoje niezadowolenie, niejako „na siłę” próbują zmieniać wzory zachowań i normy życia rodzinnego, sugerując, że małżeństwo mogą tworzyć dwie osoby tej samej płci.

Warto zwrócić uwagę, że uwarunkowania towarzyszące procesowi wychowania mogą mieć wymiar pozytywny, jak i negatywny. O tym pierwszym możemy mówić 
wtedy, gdy odnosi się do organizowanych przez rodziców czy opiekunów dzieci i młodzieży sytuacji wychowawczych, ukierunkowanych na dobry kontakt i silną z nimi więź, nie tylko poprzez zaspokojenie podstawowych potrzeb, ale również umożliwienie nabywania różnorodnych doświadczeń, korzystnych z punktu widzenia prawidłowego rozwoju jednostki.

Jak słusznie zauważa Marian Nowak, „W oddziaływaniach wychowawczych i wzajemnych relacjach wychowawca-wychowanek należy zatem zatroszczyć się świadomie, celowo i w pełni o aksjologicznie uzasadniony dobór wartości, które chcemy, by stały się udziałem wychowanka. jeśli wychowawca nie stawiałby sobie żadnego celu, to wówczas nie byłby też potrzebny, aby zajmować się wychowankiem. Wychowanie i nauczanie są nie do pomyślenia bez postawienia problemu celu wychowania, a więc nie istnieją one bez wartościowania i bez wartości. to właśnie dlatego aspekty aksjologiczne nie mogą zniknąć z pola widzenia pedagogiki i szkolnej praktyki edukacyjnej, a zwłaszcza ze wzajemnych osobowych relacji nauczyciel-uczeń, wychowawca-wychowanek" (Nowak 2019, s. 19).

Nauczanie Prymasa Wyszyńskiego, dotyczące spraw rodziny, małżeństwa i wychowania, ukazywane jest na tle godności osoby ludzkiej oraz powołania do świętości każdego człowieka. „W rodzinie jesteśmy otoczeni ludźmi, którzy pochodzą z miłości Boga. Matkom, które mają wątpliwości: urodzić dziecko czy nie, należałoby uświadomić, że to Bóg chce tych dzieci. Są one zaplanowane nie tylko przez rodziców, są chciane i zaplanowane przez Boga Ojca. Są owocem nie tylko miłości dwojga rodziców, ale miłości Boga. W ten sposób życie rodziny domowej wiąże się z jej głównym Autorem - z Bogiem" (Wyszyński 1979a, s. 28).

Dla Prymasa Stefana Wyszyńskiego rodzina jest podmiotem życia społecznego i zarazem miejscem życia i urzeczywistniania się człowieka jako osoby.

W kręgu inspiracji nauką Prymasa Wyszyńskiego pozostawał Jan Paweł II. Z adhortacji apostolskiej Ojca Świętego Jana Pawła II: O zadaniach rodziny chrześcijańskiej wświecie współczesnym „Familiaris Consortio” dowiadujemy się o prawach - obowiązkach rodziców do wychowania dzieci, które wiążą się z kształtowaniem dzieci w wierze i praktyce życia chrześcijańskiego. „Prawo - obowiązek rodziców do wychowania jest czymś istotnym i jako taki związany jest $\mathrm{z}$ samym przekazywaniem życia ludzkiego; jest on pierwotny i mający pierwszeństwo w stosunku do zadań wychowawczych innych osób, z racji wyjątkowości stosunku miłości łączącej rodziców i dzieci; wyklucza zastępstwo i jest niezbywalny, dlatego nie może być całkowicie przekazany innym, ani przez nich zawłaszczony" (Jan Paweł II 1981).

Jak słusznie zauważa Marian Nowak, „Nie tylko rodzice i najbliżsi dorośli są odpowiedzialni za pełny i zdrowy rozwój dziecka; ta odpowiedzialność spoczywa również na całej społeczności postrzeganej jako grupa, wspólnota, parafia, ruch, diecezja, Kościół, państwo itd. Łączy się z tym fakt, że człowiek jest naturą indywidualną, ale i społeczną. Również społeczeństwo, pojęte jako wielki podmiot wychowania, staje wobec dziecka i powinno odczuwać szczególne zobowiązanie do odpowiedzialności za jego rozwój” (Nowak 1998, s. 135). 


\section{Praktyka resocjalizacyjna - w poszukiwaniu skutecznych rozwiązań}

Wydaje się, że proces wychowania może przynieść pozytywne skutki dla wychowanka, dla jego rodziny wówczas, gdy wychowanek podejmie pewien trud związany $\mathrm{z}$ wyrażeniem zgody i akceptacji przekazywanych mu treści wartości w kierunku dojrzałości i odpowiedzialności, prowadzących go do samo wychowania. W przypadku osób pozbawionych wolności zależy nam zatem, aby więźniowie pod wpływem realizowanej wobec nich działalności resocjalizacyjnej samodzielnie podejmowali decyzję o zmianie swoich zachowań i postaw. Oczywiście, nie oznacza to, że wychowawca penitencjarny wie, jaką konkretną metodę odziaływania oraz środki wychowawcze ma zastosować wobec danego więźnia, tak aby wreszcie mógł on podejmować dobre decyzje w swoim życiu. Jednocześnie nie zawsze wychowawcy penitencjarni potrafią dobierać do konkretnych skazanych właściwe środki i metody oddziaływań, tym bardziej że część z nich może nie rozumieć potrzeby i sensu ich realizowania. Bywa, że działalność taka często pozbawiona jest elementów odnoszących się wprost do „doświadczenia jednostki resocjalizowanej", poddawanej zabiegom wychowawczym w warunkach izolacji. W tym miejscu można zadać pytanie, o jakie doświadczenie nam chodzi.

Warto więc podjąć się próby jego zdefiniowania i przyjąć, że „doświadczenie jednostki resocjalizowanej" możemy odbierać jako pewną sytuację odnoszącą się do istoty życia i funkcjonowania człowieka pozbawionego wolności, na którą składa się doznanie oraz aktywne uczestnictwo w procesie resocjalizacji zachodzące w środowisku, jakim jest konkretny zakład karny, czy areszt śledczy. Z punktu widzenia potrzeb współczesnej działalności penitencjarnej, a zatem sytuacji dotyczącej „doświadczenia jednostki resocjalizowanej”, warto jest bliżej przyjrzeć się problematyce prymasowskiego nauczania, opartego na miłości i służbie wobec każdego człowieka.

Nauczanie prymasowskie bogate jest w treści oparte na poszanowaniu wartości ogólnoludzkich, których odniesienie do praktyki wychowawczej, realizowanej $\mathrm{w}$ warunkach izolacji więziennej, zdaniem autora, jest niezwykle ważne.

Jak wiemy, wartości bowiem stanowić mogą pewnego rodzaju podłoże dla właściwego przebiegu procesu wychowania resocjalizacyjnego. $Z$ jednej strony, pozwalają osobom pozbawionym wolności na dokonywanie właściwych wyborów, finalizując tym samym rozpoczęty proces resocjalizacji, $z$ drugiej zaś strony, łagodzą skutki prizonizacji, związanej z nadmiernym przystosowaniem się do warunków zakładu karnego. W odkrywaniu przez więźniów „świata wartości” równie pomocne może okazać się odwoływanie do doświadczeń wiary oraz moralności chrześcijańskiej, na podstawie których kształtuje się sumienie, pełniące niejako funkcję drogowskazu do zachowań społecznie akceptowanych.

W tym miejscu warto wspomnieć, że jednym z najistotniejszych elementów sprzyjających readaptacji społecznej więźniów jest obecność i działalność na terenie zakładów karnych w Polsce instytucji duszpasterstwa więziennego. Działalność ta 
polega na realizowaniu posługi religijnej na terenie więzień w stosunku do więźniów poprzez wzbudzanie wiary i świadczenie miłości caritas (Machel 2003, s. 282).

$\mathrm{W}$ praktyce resocjalizacyjnej równie ważnym zadaniem jest „podejmowanie działań zmierzających do rozwoju samoświadomości podopiecznego” (Fidelus 2018, s. 131), pozwalającej na przetworzenie potencjału jednostki w kierunku samowyzwolenia się od ograniczeń i wadliwych zachowań.

W takiej działalności resocjalizacyjnej chodzi również o wzbudzenie motywacji do „moralnej odnowy” każdego więźnia, co pozwala na przezwyciężenie życiowych niepowodzeń.

W trakcie rozmów, jakie mogłem przeprowadzić z więźniami, zauważyłem, że dla wielu $z$ nich pragnienie wiary może być odpowiedzią na doświadczenia związane z samotnością oraz potrzebą bliskości z drugim człowiekiem. Więźniowie chętnie mówili o doświadczeniach i wartościach, jakie są obecne w działalności i nauczaniu Ojca Świętego Jana Pawła II oraz Prymasa Tysiąclecia Stefana Wyszyńskiego.

Pomocnymi w przekazywaniu wiedzy o tych dwóch wielkich Polakach są kapelani więzienni, sprawujący swoją posługę na terenie więzień.

Obecność oraz działalność kapelanów w jednostkach penitencjarnych wydaje się sprawą niezwykle ważną i konieczną, dodatkowo wpływa bowiem pozytywnie na jednostkę niedostosowaną społecznie, kształtując jej postawę i osobowość, tym samym zapobiega zjawisku wykluczenia i demoralizacji. Działalność duszpasterstwa więziennego wiąże się z dużym zaangażowaniem i ofiarnością osób świadczących tę formę pomocy drugiemu człowiekowi, której inicjatywa ma wymiar społeczny, kulturowo-oświatowy, a przede wszystkim duchowy.

Dokonanej przez autora analizie treści zawartych w materiałach źródłowych dotyczących Sługi Bożego Stefana Wyszyńskiego towarzyszy perspektywa pedagogiczna oparta na elementach jego nauki i przesłania, charakterystycznego dla wychowania chrześcijańskiego.

Takie wychowanie jest podstawą humanistycznego porządku społecznego uwzględniającego przyrodzoną godność i wielkość każdego człowieka, bez względu na status społeczny, wynikający również z faktu pozbawienia wolności. Ideał życia ukazany na kartach Ewangelii, a zaproponowany w nauczaniu Prymasa Tysiąclecia, ukazuje wartości specyficznie dla chrześcijaństwa. Jak podkreśla Marian Nowak (2000, s. 395-396), „chrześcijanie przyjmują wartości ogólnoludzkie, ale poszukują ich jeszcze większej głębi, ich pełni i integralności, poszukują sensu przekraczającego ten, który zdolny jest nadać im człowiek. Poszukuje się bowiem w chrześcijaństwie jeszcze i tej perspektywy patrzenia na wartości, jaką ma sam Bóg (Objawienie)".

W takim wychowaniu autor dostrzega duży „potencjał naprawczy” dla systemu penitencjarnego w Polsce. Warto również zwrócić uwagę, że w przypadku osób pobawionych wolności takie wychowanie może być prawdziwie pomocne przy ich nawróceniu związanym z wyrażeniem żalu za wyrządzone zło czy też przestępstwo 
z postanowieniem poprawy. Pozwala na rozwijanie i doskonalenie w człowieku sfery odpowiedzialnej za sposób rozumienia wartości.

\section{Zakończenie}

Ostatecznie w refleksji nad zagadnieniem uwarunkowań towarzyszących procesowi resocjalizacji chodzi o ukształtowanie fundamentalnych i podstawowych wartości człowieka, który traktuje swoją godność osobową jako niezbywalną wartość (Wierzbicki 2020, s. 217). Zajmuje ona centralną pozycję w nauczaniu Prymasa Wyszyńskiego.

W tym kontekście szczególnego znaczenia nabierają wskazania dotyczące postępowania z osobami pozbawionymi wolności, utrwalone w przepisach prawnych gwarantujących respektowanie godności człowieka. Międzynarodowe standardy dotyczące postępowania z osobami pozbawionymi wolności stanowią, że każdy więzień musi być traktowany podmiotowo. Ponadto należy stwierdzić, że pojęcie praw więźnia, jego godności, do której jest on upoważniony, wynika z faktu niekwestionowanego prawa każdego człowieka do życia.

Jak podkreślał Prymas Stefan Wyszyński: „Godność człowieka nie zależy od tego, jaką wykonuję pracę, jakie studia ukończył, czego się nauczył, jakie zajmuje stanowisko. Wynika ona ze świadomości, że człowiek jest mieszkaniem Boga, że Bóg w nim mieszka, że ciało jego jest poświęcone Bogu, że każdy z nas ma nosić i czcić Boga w ciele swoim. [...] Chrześcijaństwo ustanawia we współczesnym świecie nową ocenę wartości osoby. Kryteria tej oceny są pozaekonomiczne. Chrześcijaństwo nie ocenia człowieka według tego, «ile masz», tylko według tego, «kim jesteś», «jaki jesteś»” (Wyszyński 1987, s. 86).

\section{Bibliografia}

Fidelus A. (2018). Rola samoświadomości w modelu relacyjnej readaptacji społecznej skazanych. „Przegląd Więziennictwa Polskiego”, nr 100, s. 131-145.

Jan Paweł II. (1999). Pielgrzymki do Ojczyzny: 1979, 1983, 1987, 1991, 1995, 1997, 1999. Przemówienia, homilie, Poniewierski J. (red.). Kraków: Wydawnictwo „Znak”.

Jan Paweł II. (2006). Adhortacja apostolska „Familiaris Consortio" o zadaniach rodziny chrześcijańskiej w świecie wspótczesnym. W: Adhortacje Apostolskie Ojca Świętego Jana Pawła II. T. 1: 1979-1995. Kraków: Wydawnictwo „Znak”.

Jan Paweł II. (2019). Dzieła literackie i teatralne. T. 1: Juwenilia (1938-1946). Popiel J. (red.). Kraków: Wydawnictwo „Znak”.

Nowak M. (1998). Funkcja wychowawcza matki i ojca wedtug pedagogii personalistyczno-chrześcijańskiej. „Roczniki Nauk Społecznych”, t. XXVI, z. 2, s. 107-139.

Nowak M. (2000). Podstawy pedagogiki otwartej. Ujęcie dynamiczne w inspiracji chrześcijańskiej. Lublin: Redakcja Wydawnictw KUL. 
Nowak M. (2019). Aksjologia współczesnej pedagogiki resocjalizacyjnej jako podstawa jej sukcesu. „Roczniki Nauk Społecznych”, t. 11 (47), s. 17-28.

Machel H. (2003). Więzienie jako instytucja karna i resocjalizacyjna. Gdańsk: Wydawnictwo ARCHE.

Wach T. (2009). Resocjalizacja nieletnich sprawców gwałtownych czynów zabronionych. Lublin: Wydawnictwo „KUL”.

Wierzbicki K. (2020). Społeczna troska o rozwój osoby ludzkiej w nauczaniu Świętego Jana Pawła II skierowanym do skazanych i kadry więziennej W: Przesławski T. (red.). W poszukiwaniu dobra w perspektywie jednostkowej i społecznej. Ksiega jubileuszowa z okazji 8o-lecia urodzin Profesor Krystyny Ostrowskiej. Warszawa: Wydawnictwo IWS, WSKiP. Wyszyński S. (1975). Listy pasterskie Prymasa Polski 1946-1974. Paris: Éditions du Dialogue, Sociéte d'Éditions Internationales.

Wyszyński S. (1982). Zapiski więzienne. Paris: Dialogue/Znaki Czasu.

Wyszyński S. (1995). Dzieła zebrane. T. 2: 1953-1956. Warszawa: Wydawnictwo im. Stefana Kardynała Wyszyńskiego „Soli Deo”.

Wyszyński S. (2001). Zapiski więzienne. Warszawa-Ząbki: Wydawnictwo im. Stefana Kardynała Wyszyńskiego „Soli Deo”.

Wyszyński S. (2008). Dzieła zebrane. T. 7: 1961. Warszawa: Wydawnictwo im. Stefana Kardynała Wyszyńskiego.

Wyszyński S. (2017a). Pro memoria. T. 1: 1948-1952. Skibiński P. (red.). Warszawa: Archidiecezja Warszawska i Archidiecezja Gnieźnieńska, IPN-Komisja Ścigania Zbrodni przeciwko Narodowi Polskiemu, UKSW.

Wyszyński S. (2017b). Pro memoria. T. 2: 1953. Czaczkowska E. (red.). Warszawa:

Archidiecezja Warszawska i Archidiecezja Gnieźnieńska, IPN-Komisja Ścigania Zbrodni przeciwko Narodowi Polskiemu, UKSW.

Wyszyński S. (2018). Pro memoria. T. 5: 1958. Krupecka M. (red.). Warszawa: USJK, IPN, Archidiecezja Warszawska i Archidiecezja Gnieźnieńska, UKSW.

Wyszyński S. (2019a). Pro memoria. T. 6: 1959. Łeszczyński G. (red.). Warszawa: IPN, Archidiecezja Warszawska i Archidiecezja Gnieźnieńska, UKSW.

Wyszyński S. (2019b). Pro memoria. T. 8: 1961. Wiśniewska M. (red.). Warszawa: IPN, Archidiecezja Warszawska i Archidiecezja Gnieźnieńska, UKSW, Instytut Prymasowski, Muzeum Jana Pawła II i Prymasa Wyszyńskiego.

Wyszyński S. (2020). Pro memoria. T. 4: 1956-1957. Białkowski M. (red.). Wiśniewska M.

(współpraca). Warszawa: IPN, Archidiecezja Warszawska i Archidiecezja Gnieźnieńska, UKSW.

\section{Źródła internetowe}

https://muzhp.pl/pl/

https://www.niedziela.pl/artykul/77068/nd/Ojciec-Swiety-Jan-Pawel-II-o-Stefanie https://opoka.org.pl/nauczanie/nauczanie-papieza-jana-pawla-ii-przemowienia-i-oredzia https://wyszynskiprymas.pl/ 
https://www.vaticannews.va/pl/kosciol/news/2020-05/polska-wyszynski-nie-byloby-tego-papieza-polaka.html

https://www.vatican.va/content/john-paul-ii/pl/apost_exhortations/documents/hf_jp-ii_exh_19811122_familiaris-consortio.html

\title{
ACTIVITIES AND TEACHING THE SERVANT OF GOD STEFAN WYSZYNSKI - PEDAGOGICAL IMPLICATIONS FOR PENITENTIAL PRACTICE
}

\begin{abstract}
The many years of activity of the Servant of God Stefan Wyszynski for the Church in Poland and the defense of Polish identity are visible in the field of searching for the face of contemporary values in the context of upbringing, characteristics of Christianity. This article presents in a synthetic way the specific features of the spiritual figure and selected facts from the life of the future blessed, the Primate of the Millennium, Stefan Wyszyński, which emerge on the basis of the analysis of his activities and teaching. The source of knowledge about the primate were his speeches, sermons, homilies, notes from the time when he was imprisoned. The issue of research on the figure and heritage of Primate Stefan Wyszyński is visible in the author's need for research on the experience of faith and the possibility of using the reality he learns in the pedagogical practice of social rehabilitation education.
\end{abstract}

Keywords: Primate Stefan Wyszyński; Christian education; penitentiary practice; dignity. 
